\title{
PEMBERDAYAAN MASYARAKAT DALAM MENINGKATKAN KEMAMPUAN KEPEMANDUAN WISATA DI DESA WISATA CIBUNTU KAB. KUNINGAN PROVINSI JAWA BARAT
}

\section{THE COMMUNITY EMPOWERMENET IN IMPROVING TOURIST GUIDING CAPABILITY IN TOURISM VILLAGE CIBUNTU DISTRICT OF KUNINGAN WEST JAVA PROVINCE}

\author{
K Fajri'1a, T Kartika ${ }^{1}$, L Afriza ${ }^{1}$ \\ 'STIEPAR Yapari Bandung, Jln. Prof Dr. Sutami No 81-83 Bandung \\ ${ }^{a}$ Korespondensi: Titing Kartika; E-mail: nengtiting_kartika@yahoo.co.id \\ (Diterima: 06-09-2019; Ditelaah: 08-09-2019; Disetujui: 18-01-2020)
}

\begin{abstract}
Desa Cibuntu (Cibuntu Village) is a tourism-based village located at the foot of Mount Ciremai, Pasawahan District, Kuningan, West Java. The village is located approximately $20 \mathrm{KM}$ from the center of Kuningan City. Cibuntu Village has a variety of uniqueness that is owned both in nature, culture, and history. Cibuntu Village is declared as a Tourism Village as stipulated in the Decree of the Head of the Kuningan District Tourism and Culture Office Number 55631 / KPTS.178.A Disparbud / 2012 concerning the designation of Cibuntu Village as an Object and Attraction (Tourism Village). Guiding tours become very important because they are part of the service. Lack of communication skills and mastery of English become the main obstacle in guiding tourism activities in the Cibuntu Tourism Village. The people who are assigned as guides seem to only have capital, so the delivery of information is not packaged properly to tourists. Referring to these conditions, then the solution is coaching and mentoring in an effort to improve the ability to guide tours through a series of training. The training will be classified into two categories, namely tour guides and English training for tour guides. The methods to be used include lectures, questions and answers, discussions. To improve the ability to guide in English will focus on drilling models and role play. As targets to be achieved are (a) increasing the ability to understand the role of the tour guide, (b) increasing the ability of the community in the tour guide, (c) increasing the ability of English in guiding activities especially when guiding foreign tourists, (d) increasing communication skills when guiding the tour. To achieve these targets the activity implementation team will work together with the association of Indonesian tour guides and professional guides.
\end{abstract}

Keywords: Community Empowerment , Tourism Village, Tour Guide.

\section{ABSTRAK}

Desa Cibuntu merupakan sebuah desa berbasis wisata yang terletak di kaki gunung ciremai Kecamatan Paswahan Kabupaten Kuningan Jawa Barat. Desa tersebut terletak kurang lebih 20 KM dari pusat Kota Kuningan. Desa Cibuntu memiliki ragam keunikan yang dimiliki baik secara alam, budaya maupun sejarah. Desa Cibuntu dinyatakan sebagai Desa Wisata tertuang dalam Surat Keputusan Kepala Dinas Pariwisata dan Kebudayaan Kabupaten Kuningan Nomor 55631/KPTS.178.A Disparbud/2012 tentang penetapan Desa Cibuntu sebagai Objek dan Daya Tarik Wisata (Desa Wisata). Kegiatan memandu wisata menjadi sangat penting karena bagian dari pelayanan. Kurangnya kemampuan berkomunikasi serta penguasaan bahasa Inggris menjadi kendala utama dalam kegiatan memandu wisata di Desa Wisata Cibuntu. Masyarakat yang bertugas sebagai pemandu seolah hanya bermodal apa adanya, sehingga penyampaian informasi tidak dikemas dengan baik kepada wisatawan. Mengacu pada kondisi tersebut, maka sebagai solusinya adalah pembinaan serta pendampingan dalam upaya meningkatkan kemampuan memandu wisata melalui rangkaian pelatihan. Pelatihan akan diklasifkasikan menjadi dua kategori yaitu kepemanduwisataan (tour guide) dan pelatihan bahasa Inggris bagi tour guide. Metode yang akan digunakan diantaranya ceramah, tanya jawab, diskusi. Untuk peningkatan kemampuan memandu dalam bahasa Inggris akan 
difokuskan pada model drilling dan role play. Sebagai target yang akan dicapai adalah (a) meningkatkan kemampuan mengenai pemahaman peran dari pemandu wisata, (b) meningkatkan kemampuan masyarakat dalam kepemanduwisataan, (c) meningkatkan kemampuan bahasa Inggris dalam kegiatan memandu khususnya ketika memandu wisatawan asing, (d) meningkatkan kemampuan berkomunikasi saat memandu wisata. Untuk mencapai target tersebut tim pelaksana kegiatan akan bekerjasama dengan asosiasi himpunan pramuwisata Indonesia serta guide profesional

Kata Kunci : Desa Wisata, Pemandu wisata, Pemberdayaan Masyarakat.

Fajri, K., Kartika, T., \& Afriza, L. (2020). Pemberdayaan Mayarakat Dalam Meningkatkan Kemempuan Kepemanduan Wisata di Desa Wisata Cibuntu Kab. Kuningan Provinsi Jawa Barat. Jurnal Qardhul Hasan : Media Pengabdian kepada Masyarakat, 6(1), 28-38.

\section{PENDAHULUAN}

Indonesia memliliki kekayaan alam serta keragaman budaya. Keragaman inilah yang menjadikan setiap daerah di Indonesia memiliki keunikan tersendiri.Kehidupan tradisional dan nuansa etnik masih banyak tersebar di wilayah desa-desa di Indonesia. Bagi wisatawan keuninikan dan nilai tradisional itulah yang menjadi daya tarik tersendiri. Kementrian Pariwisata RI melihat keragaman sebagai potensi wisata yang dikembangkan dalam konsep desa wisata.

Desa wisata merupakan suatu kawasan pedesaan yang menawarkan keseluruhan suasana yang mencerminkan keaslian pedesaan, baik dari kehidupan sosial, ekonomi, sosial budaya, adat istiadat , keseharian, memiliki arsitketur bangunan dan struktur tata ruang desa yang kahas atau kegiatan perekonomian yang unik dan menarik, serta mempunyai potensi untuk dikembangkan berbagai komponen kepariwisataan seperti atraksi, akomodasi, makanan -minuman, cinderamata, dan kebutuhan wisata lainnya. (Pesona Desa Wisata Indonesia, Kemenpar 2014). Keberadaan Desa Wisata di Indonesia mengalami perkembangan yang pesat. Berdsaarkan data Kementrian Pariwisata terdapat 978 Desa Wisata dimana sebelumnya pada tahun 2009 hanya tercatat 144 Desa.

Seiring dengan perkembangan dari desadesa wisata di Indonesia saat ini, salah satunya Desa Wisata Cibuntu terus meningkatkan pelayanan kepada pengunjung baik wisatawan domestik maupun mancanegara. Salah satu pelayanan yang sangat penting yakni bagaimana memandu wisatawan. Melalui kegiatan pengabdian ini, difokuskan bagaimana pemberdayaan masyarakat dala meningkatkan kemampuan kepemanduan. Adapun kegiatan pengabdian ini didasari oleh situasi analisis di lokus karena kurangnya pemahaman peran dan tugas pemandu wisata, kurangnya kemampuan bahasa Inggris ketika memandu serta kurangnya kemampuan teknik komunikasi dalam memandu.

\section{MATERI DAN METODE}

Pemahaman lain mengenai desa wisata dijelakan oleh beberapa penulis. Darsono (2015) menjelaskan bahwa desa wisata merupakan suatu wilayah pedesaan yang menawarkan keaslian baik dari segi sosial budaya, adat istiadat, keseharian, arsitektur tradisional, struktur tata ruang desa yang disajikan dalam suatu bnetuk integrasi komponen pariwisata antara lain seperti atraksi, akomodasi dan fasilitas pendukung. Sementara itu (Sastrayuda, 2010), mengungkapkan bahwa ramuan utama desa wisata diwujudkan dalam gaya hidup dan kualitas hidup masyarakatnya yang dipengaruhi oleh keadaan ekonomi, fisik dan sosial daerah pedesaan tersebut. Keaslian suatu pedesaan akan memperkuat identitas diantaranya meliputi ruang, warisan budaya, kegiatan pertanian, 
bentangan alam, pariwisata sejarah dan budaya, serta pengalaman yang unik dan eksotis khas daerah.

Desa Cibuntu dinyatakan sebagai Desa Wisata tertuang dalam Surat Keputusan Kepala Dinas Pariwisata dan Kebudayaan Kabupaten Kuningan Nomor 55631/KPTS.178.A Disparbud/2012 tentang penetapan Desa Cibuntu sebagai Objek dan Daya Tarik Wisata (Desa Wisata). Hasil tersebut telah melalui beberapa kajian bersama masyarakat, industri dan akademisi. Diantaranya mengacu pada prinsip pengembangan yang dijelaskan oleh (Sastrayuda, 2010) bahwa pengembangan desa wisata memiliki kritera sebagai berikut: memanfaatkan sarana dan prasarana masyarakat setempat; menguntungkan

setempat; berskala kecil untuk memudahkan terjalinnya hubungan timbal balik dengan masyarakat setempat; melibatkan masyarakat setempat; menerapkan pengembangan produk wisata pedesaan.

Dalam mendukung capaian sebagai Desa Wisata, Desa Cibuntu memiliki potensi wisata yang layak menjadi sebuah daya tarik baik alam, budaya maupun sejarah.

Tabel 1. Potensi Wisata Desa Cibuntu Kab. Kuningan.

\begin{tabular}{|l|l|l|}
\hline No. & $\begin{array}{l}\text { Jenis } \\
\text { Potensi }\end{array}$ & Deskrispi \\
\hline 1 & Alam & $\begin{array}{l}\text {-Bentangan alam di } \\
\text { bawah kaki gunung } \\
\text { Ciremai } \\
\text {-Nuansa persawahan } \\
\text {-Nuansa peternakan } \\
\text { (kampung Kambing) } \\
\text {-Lahan pertanian dan } \\
\text { perkebunan } \\
\text {-Kegaiatn agrowisata } \\
\text {-Camping ground } \\
\text {-Mata Air Kahuripan } \\
\text {-Air Terjun Bosreng }\end{array}$ \\
\hline 2 & Seni & $\begin{array}{l}\text {-Upacara Adat sedekah } \\
\text { Bumi } \\
\text {-Sanggar seni }\end{array}$ \\
\hline
\end{tabular}

\begin{tabular}{|l|l|l|}
\hline 3 & Sejarah & $\begin{array}{l}\text { Adanya situs purbakala } \\
\text { (a) Situs Bujal Dayeuh; } \\
\end{array}$ \\
& & $\begin{array}{l}\text { (b) Situs Hulu Dayeuh; } \\
\text { (c) Situs Sahurip Kaler; } \\
\text { (d) Situs Sahurip Kidul; } \\
\text { (e) Situs Cikahuripan; }\end{array}$ \\
\hline 4 & Ekonomi & -Pengolahan grabah \\
& Kreatif & -Pengolahan kuliner lokal \\
\hline
\end{tabular}

Dalam implementasinya, pengelolaan Desa wisata Cibuntu melibatkan banyak pihak baik pemerintah, masyarakat melalui kompepar (kelompok penggerak pariwisata), akdemisi (melalui tahapan kajian dan penelitan), industri dan media. Mengacu pada hasil penelitian sebelumnya yang dilaksanakan oleh tim, sinergitas lini sektor tersebut masih belum terintegrasi secara optimal. Upaya lain yang sudah dilakukan adalah dengan pembuatan paket wisata. Paket wisata yang telah dibuat berdasarkan sebaran potensi yang ada di desa wisata Cibuntu.

Berikut adalah beberapa paket wisata yang tertuang dalam itinerary yang disediakan oleh pengelola :Paket Tour 1 Hari tanpa mengina; Paket Tour 2 Hari 1 malam; Paket tour 3 hari 2 malam; Paket Family camping 2 hari 1 malam; Paket Pelatihan Gerabah 1 hari; Paket Outbound anak 1 hari.

Pengembangan ideal dalam suatu pariwisata adalah dengan melibatkan masyarakat lokal, seperti yang tertuang dalam Piagam Pariwisata Berkelanjutan (1995) yaitu "Pembangunan pariwisata harus didasarkan pada kriteria keberlanjutan yang artinya bahwa pembangunan dapat didukung secara ekologis dalam jangka panjang sekaligus layak secara ekonomi, adil secara etika dan sosial terhadap masyarakat". Sementara itu (Adiyoso, 2009) menegaskan bahwa keterlibtan partisipasi masyarakat merupakan komponen terpenting dalam upaya pertumbuhan kemnadirian dan proses pemberdayaan

Berdasarkan hasil penelitian tim (2018), meskipun Desa Cibuntu telah memenuhi kriteria sebagai Desa Wisata dan telah 
berupaya dalam melibatkan masyarakat lokal, namun dalam tataran implementasinya masih ditemukan adanya permasalahan dianataranya adalah belum optimalnya kemampuan masyarakat dalam kegiatan memandu wisata. Masalah ini dapat dipahami dikarenakan oleh beberapa faktor diantaranya:Keterbatasan latar belakang pendidikan, berdasarkan informasi dari desa Cibuntu, masyarakat desa sebagian besar adalah tamatan SMP; Kurangnya pemahaman peran dan fungsi dari pemandu wisata; Kurangnya pemahaman akan produk wisata yang ditawarkan; Kurangnya pengetahuan dalam bidang komunikasi hospitaliti.

Dalam kegiatan wisata kehadiran seorang pemandu wisata (pramuwisata) sangat penting. Pramuwisata adalah seseorang yang memimpin wisatawan dan memberikan informasi tentang segala sesuatu yang memiliki daya tarik bagi wisatawan (Harum, 2012). Secara spesifik seorang parmuswisata adalah orang yang mempunyai pengetahuan mengenai objek wisata secara khusus,mendalam mengenai satu atau lebih objek wisata, seperti kebudayaan, arkeologi, sejarah, teknik, pedagangan, keamanan, ilmiah, marga satwa peburuhan dan lain-lain. Selain itu juga pramuwisata yang profesional adalah yang mempunyai izin usaha atau kegiatan yang membimbing perjalanan dan memberikan penerangan kepada wisatawan, baik sebagai penerangan kepada wisatawan baik sebagai perorangan atau sebagai kelompok dengan menggunakan satu atau beberapa bahasa tertentu.

Bahasa Inggris salah satunya, Dengan demikan pelatihan dalam upaya meningkatkan kemampuan bahasa Inggris khsussnya dalam aspek guiding menjadi syarat mutlak. Leo (2016) menjelaskan bahwa aspek bahasa Inggris yang diperlukan dalam pelayanan memandu wisata diantaranya:Greeting and welcoming tourist; Asking and giving tourist information; Preparing tour itineraries

Orientation meeting and briefing;Guiding commentary on the way; Giving local food service information; Telling a legend; Suggesting places interest to visit; Dealing with unexpected tour events; Handling tourists' complaints; Explaining safely, rules, etiquestee and customs; Closing dan reporting tour activity; Designing tourist brochures; Planning packages tours; Jobs of tour guide, opeartor and manager; Applying for a job; Attending a job interview.

\section{Permasalahan dan Solusinya}

Permasalahan yang ditemukan di lapangan adalah : Kurangnya pemahaman peran dan tugas pemandu wisata; Kurangnya kemampuan bahasa Inggris dalam kegiatan memandu; Kurangnya kemampuan teknik komunikasi dalam memandu.

Untuk memecahkan permasalahan yang terjadi di Desa Wisata Cibuntu berkaitan dengan kegiatan Kepemanduan wisata. Ceramah, diskusi, tanya jawab mengenai peran dan tugas yang disampaikan oleh pemandu wisata yang sudah bersertifikasi. Pelatihan bahasa Inggris mengenai kegiatan kepemanduan wisata sesuai dengan potensi wisata yang dimiliki. Teknik yang digunakan adalah drilling dan role play (bermain peran)Pelatihan teknik komunikasi dalam memandu.

\section{Tujuan Pengabdian}

Meningkatkan pemahaman mengenai peran dan tugas seorang Pemandu Wisata. Melatih kemampuan dalam penggunaan bahasa asing khususnya bahasa Inggris saat melakukan kegiatan pemanduan wisata oleh setiap individu masyarakat yang bertanggungjawab untuk memberikan penjelasan-penjelasan disetiap bidangnya kepada tamu-tamu asing khususnya bahasa Inggris. Meningkatkan kemampuan dalam teknik melakukan kepemanduan wisata sesuai dengan standar-standar kompetensi minimal dalam hal kepemanduan.

\section{Manfaat Pengabdian}

Dapat meningkatkan pemahaman tentang peran dan tugas seorang pemandu wisata bagi penduduk desa wisata Cibuntu yang akan bertugas sebagai pemandu wisata 
lokal.Sebagai momentum kegiatan yang dapat dimanfaatkan oleh masyarakat desa wisata untuk meningkatkan teknik dan wawasan dalam kegiatan kepemanduan wisata.Sebagai masukan kepada pemerintah setempat khususnya untuk meningkatkan kegiatan-kegiatan pelatihan yang berhubungan dan dapat dilakukan secara langsung oleh masyarakat desa wisata.

\section{Mitra Pengabdian}

Dalam kegiatan pengabdian yang merupakan program kemitraan masyarakat yang dilaksanakan oleh Tim STIEPAR dengan pendanaan dari hibah RISTEKDIKTI tahun anggaran 2019 di Desa Wisata Cibuntu Kuningan Jawa Barat yang juga merupakan kegiatan pengembangan desa wisata yang berbasis masyarakat. Pada aspek pengelolaannya melibatkan peran dan partisipasi masyarakat, kelembagaan dari pemerintah setempat dan organisasi atau asosiasi profesi. Adapun mitra-mitra yang terlibat dalam kegiatan pengabdian antara lain :Dinas Pemuda, Olahraga dan Pariwisata kabupaten Kuningan; Pemerintah desa Cibuntu kecamatan Pasawahan kabupaten Kuningan; Kelompok penggerak pariwisata desa wisata Cibuntu (Kompepar); Himpunan Pramuwisata Indonesia DPC Kab. Cirebon (HPI).

\section{METODE PELAKSANAAN}

Pengabdian ini menggunakan pendekatan metode pelatihan dengan sumber utama proses penekanan kepada kemampuan, pengetahuan, keterampilan dan sikap, sebagaimana pengertian pelatihan menurut Notoatmodjo (2009:16) "Pelatihan merupakan upaya yang berkaitan dengan peningkatan kemampuan atau keterampilan karyawan yang sudah menduduki suatu pekerjaan atau tugas tertentu". Dan bukan dengan pendekatan metode pendidikan sebagaimana perbedaan pengertian lebih lanjut antara metode pendidikan dengan pelatihan menurut Notoatmodjo :
Tabel 2. Perbandingan Pendidikan dan Pelatihan.

\begin{tabular}{|c|l|l|l|}
\hline NO & \multicolumn{1}{|c|}{ ASPEK } & PENDIDIKAN & PELATIHAN \\
\hline 1 & $\begin{array}{l}\text { Pengembangan } \\
\text { kemampuan }\end{array}$ & $\begin{array}{l}\text { Menyeluruh } \\
\text { (overall) }\end{array}$ & $\begin{array}{l}\text { Khusus } \\
\text { (specific) }\end{array}$ \\
\hline 2 & $\begin{array}{l}\text { Area } \\
\text { kemampuan } \\
\text { (penekanan) }\end{array}$ & Kognitif, afektif & Psikomotor \\
\hline 3 & $\begin{array}{l}\text { Jangka waktu } \\
\text { pelaksanaan }\end{array}$ & $\begin{array}{l}\text { Panjang (long } \\
\text { term) }\end{array}$ & $\begin{array}{l}\text { Pendek (short } \\
\text { term) }\end{array}$ \\
\hline 4 & $\begin{array}{l}\text { Materi yang } \\
\text { diberikan }\end{array}$ & Lebih umum & Lebih khusus \\
\hline 5 & $\begin{array}{l}\text { Penekanan } \\
\text { penggunaan } \\
\text { metode }\end{array}$ & $\begin{array}{l}\text { Konventional } \\
\text { melajar }\end{array}$ & Inconventional \\
\hline 6 & $\begin{array}{l}\text { Penghargar } \\
\text { akhir proses }\end{array}$ & Gelar (degree) & sertifikat \\
\hline & & & \\
\hline
\end{tabular}

\section{HASIL DAN PEMBAHASAN}

Sesuai dengan laporan hasil pengabdian yang dilakukan oleh Tim Program Kemitraan Masyarakat (PKM) dengan kegiatan Pemberdayaan Masyarakat dalam meningkatkan kemampuan kepemanduan wisata di desa wisata Cibuntu Kabupaten Kuningan, diketahui bahwa kegiatan pengabdian dilakukan terbagi dalam 4 (empat) tahap yaitu :Tahap kegiatan pemantapan program pelaksanaan kegiatan pelatihan (4 Maret - 31 Mei 2019). Konfirmasi dengan para mitra kegiatan baik narasumber ataupun institusi

Penguatan konsep dan jadwal kegiatan.Pertemuan dengan narasumber untuk penguatan materi pelatihan.

Gambar 1.Kegiatan Pertemuan Penguatan Konsep Pelaksanaan Pengabdian dan Bukti Absensi.
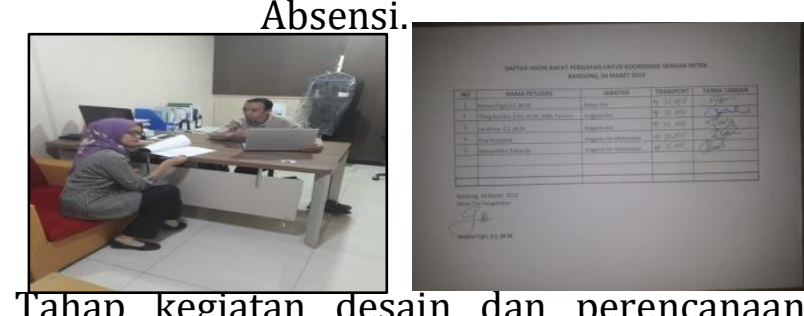
untuk pengadaan barang cetakan dan perlengkapan pendukung kegiatan (01 Juni 
2019 - 27 Juli 2019). Pengadaan format keadministrasian pelatihan untuk peserta (Absen, Biodata dll). Desain dan perencanaan atribut kegiatan pelatihan untuk peserta dan narasumber (Name tag, Kaos, Block Note, ATK). Kegiatan koordinasi dengan pihak atau mitra perangkat desa Cibuntu untuk kepastian dari tempat dan peralatan sound system, banner dan peralatan lainnya.

Gambar 2. Hasil Kegiatan Desain Perlengkapan Cetak dan Atribut Kegiatan Pengabdian.

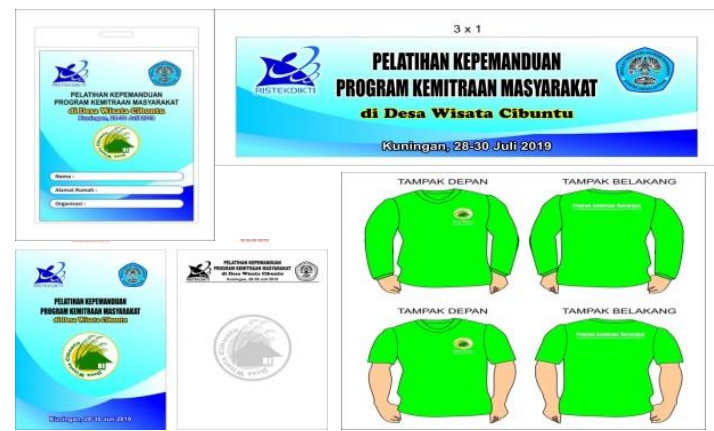

Tahap finaliasi persiapan kegiatan pelatihan (27 Juli 2019). Pengecekan seluruh barang cetakan dan perlengkapan pelatihan lainnya yang telah selesai diproduksi dan sekaligus dilakukan pengepakan.Konfirmasi kepada para mitra kegiatan antara lain : narasumber, bidang transportasi, akomodasi dan mitra Desa tempat acara untuk pelaksanaan kegiatan sesuai jadwal atau run down acara yang telah disusun.

Persiapan akhir untuk keuangan dan keadministrasian kegiatan pelatihan kepemanduan wisata sebagai bagian dari PKM.

Gambar 3. Rapat Finalisasi Persiapan kegaiatan, Pengepakan
Perlengkapan dan Penentuan Susunan Acara.
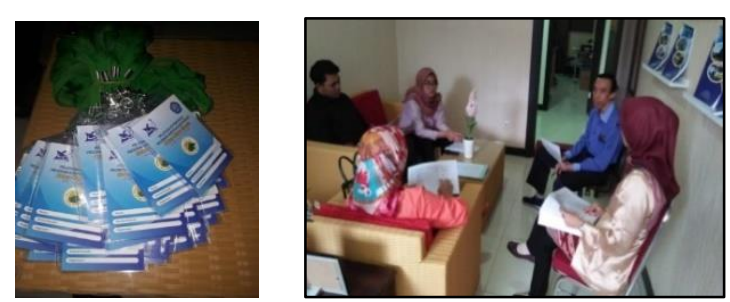

Tahap pelaksanaan kegiatan (28 - 29 Juli 2019)Kegiatan Survey lapangan, registrasi peserta pelatihan dan Diskusi penguatan data dengan pihak-pihak terkait desa (Kompepar dan perangkat desa)

Gambar 3. Perjalanan Tim Pengabdian Menuju Lokasi (28 Juli 2019).

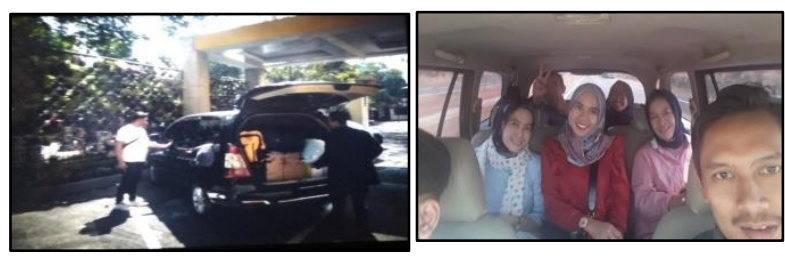

Gambar 4. Finalisasi Pemetaan Lapangan Untuk Pelatihan Praktik Pemanduan (28 Juli 2019).
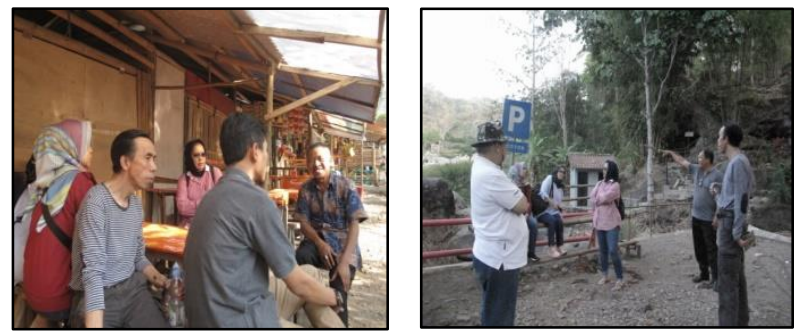

Registrasi ulang peserta pelatihan dan pelaksanaan kegiatan pelatihan. Dalam kegiatan pelaksanaan pengabdian melalui pelatihan kepemanduan wisata berdasarkan silabus yang telah disusun sebagaimana dalam tabel berikut : 
Tabel 3. Silabus Materi Pelatihan.

\begin{tabular}{|c|c|c|c|c|}
\hline Pertemuan & Materi Ajar & $\begin{array}{l}\text { Alat/Bahan/ } \\
\text { Sumber ajar }\end{array}$ & Waktu & Penilaian \\
\hline \multirow[t]{8}{*}{ Ke 1} & Wawasan Pariwisata & & $90^{\prime}$ & \\
\hline & * Pengertian dan jenis- & * Modul Materi & & Partisipasi, keaktifan \\
\hline & jenis pariwisata & ${ }^{*}$ Infocus & & peserta serta tingkat \\
\hline & * Pemahaman usaha & * Laptop & & pemahaman materi \\
\hline & dan produk bidang & $\begin{array}{l}\text { * Film-film } \\
\text { Pariwisata }\end{array}$ & & \\
\hline & Pariwisata & $\begin{array}{l}\text { (Destinasi } \\
\text { Wisata) }\end{array}$ & & \\
\hline & *Dasar Hukum kegiatan & & & \\
\hline & Pariwisata & & & \\
\hline \multirow[t]{13}{*}{ Ke 2-3 } & Etika Pelayanan & & $180^{\prime}$ & \\
\hline & Pariwisata Dan Sapta & & & \\
\hline & Pesona & & & \\
\hline & * Pengantar Pelayanan & * Modul Materi & & Partisipasi, keaktifan \\
\hline & Pariwisata & * Infocus & & peserta serta tingkat \\
\hline & * Dimensi pengharapan & * Laptop & & pemahaman materi \\
\hline & Pelanggan & $\begin{array}{l}* \text { Film-film } \\
\text { Pelayanan }\end{array}$ & & \\
\hline & $\begin{array}{l}* \text { Karakteristik } \\
\text { pelanggan }\end{array}$ & $\begin{array}{c}\text { dalam } \\
\text { pariwisata }\end{array}$ & & \\
\hline & * Simulasi praktik & & $30^{\prime}$ & Peserta dapat \\
\hline & pemberian pelayanan & * Ruang simulasi & & mempraktikan cara- \\
\hline & $\begin{array}{l}\text { pra pelaksanaan } \\
\text { wisata }\end{array}$ & $\begin{array}{l}\text { * Dokumen- } \\
\text { dokumen } \\
\text { Tour antara lain }\end{array}$ & & cara atau tahapan \\
\hline & & $\begin{array}{l}\text { Voucher Hotel, } \\
\text { Travel voucher, }\end{array}$ & & dalam pemberian \\
\hline & & rooming list & & Pelayanan \\
\hline \multirow[t]{10}{*}{ Ke 4} & Teknik Pemanduan & & $30^{\prime}$ & \\
\hline & Wisata & & & \\
\hline & $\begin{array}{l}\text { *Performa atau } \\
\text { penampilan }\end{array}$ & * Modul Materi & & Partisipasi, keaktifan \\
\hline & $\begin{array}{l}\text { seorang pemandu } \\
\text { wisata }\end{array}$ & * Infocus & & peserta serta tingkat \\
\hline & $\begin{array}{l}\text { * Memberikan Bantuan } \\
\text { pada }\end{array}$ & * Laptop & & pemahaman materi \\
\hline & $\begin{array}{r}\text { kedatangan \& } \\
\text { Keberangkatan }\end{array}$ & $\begin{array}{l}* \text { Film-film } \\
\text { Pelayanan }\end{array}$ & & \\
\hline & $\begin{array}{l}* \text { Memimpin } \\
\text { Rombongan Tour }\end{array}$ & $\begin{array}{c}\text { dalam } \\
\text { pariwisata }\end{array}$ & & \\
\hline & $\begin{array}{l}* \text { Teknik membangun } \\
\text { audience }\end{array}$ & & & \\
\hline & $\begin{array}{l}\text { * Penerapan standard } \\
\text { K3 }\end{array}$ & & & \\
\hline & $\begin{array}{l}* \text { Simulasi praktik } \\
\text { pemanduan }\end{array}$ & $\begin{array}{l}\text { * Kendaraan, } \\
\text { kantor } \\
\text { FO hotel, }\end{array}$ & $60^{\prime}$ & Peserta dapat \\
\hline
\end{tabular}




\begin{tabular}{|c|c|c|c|c|}
\hline & & kamar- & & \\
\hline & wisata & kamar hotel & & $\begin{array}{l}\text { mempraktikan cara- } \\
\text { cara atau }\end{array}$ \\
\hline & & $\begin{array}{l}\text { * Dokumen- } \\
\text { dokumen } \\
\text { Tour (Voucher } \\
\text { hotel }\end{array}$ & & Tahapan dalam \\
\hline & & Travel Voucher & & Pemanduan \\
\hline Ke 5 & $\begin{array}{l}\text { Bahasa Inggris } \\
\text { Profesi } \\
\text { Pemandu }\end{array}$ & & $30^{\prime}$ & \\
\hline & $\begin{array}{l}\text { - } \text { Greeting and } \\
\text { welcoming tourist }\end{array}$ & * Modul Materi & & \\
\hline & $\begin{array}{ll}\text { - } & \text { Asking and giving } \\
\text { tourist information }\end{array}$ & *Infocus & & \\
\hline & $\begin{array}{ll}\text { - } & \text { Preparing tour } \\
\text { itineraries }\end{array}$ & * Laptop & & \\
\hline & 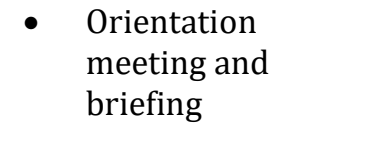 & $\begin{array}{l}\text { * Film-film } \\
\text { percakapan bhs } \\
\text { Inggris profesi } \\
\text { pemandu }\end{array}$ & & \\
\hline & $\begin{array}{l}\text { - Guiding } \\
\text { commentary on the } \\
\text { way }\end{array}$ & & & \\
\hline & $\begin{array}{l}{ }^{*} \text { Simulasi praktik } \\
\text { percakapan }\end{array}$ & $\begin{array}{l}\text { * Kendaraan, } \\
\text { kantor FO home } \\
\text { stay }\end{array}$ & $60^{\prime}$ & Peserta dapat \\
\hline & & & & mempraktikkan \\
\hline & & & & Percakapan dengan \\
\hline & & & & Bhs Inggris dasar \\
\hline
\end{tabular}

Materi bahasa Inggris untuk guiding pada kegiatan pengabdian ini akan difokuskan pada kemampuan dasar memandu meliputi: Greeting and welcoming tourist; Asking and; giving tourist information; Preparing tour itineraries; Orientation meeting and briefing; Guiding commentary on the way; Giving local food service information; Telling a legend; Suggesting places interest to visit.

Gambar 5. Kegiatan Praktik Pemanduan Wisata (29 July 2019).
Hasil yang telah dicapai setelah kegiatan pelatihan kepemanduan wisata yang dilakukan khususnya bagi para peserta dari berbagai bagian yang ada di desa wisata Cibuntu dan selanjutnya akan bertugas sebagai pemandu wisata lokal di bidangnya sebanyak 35 orang terinci dalam tabel berikut.
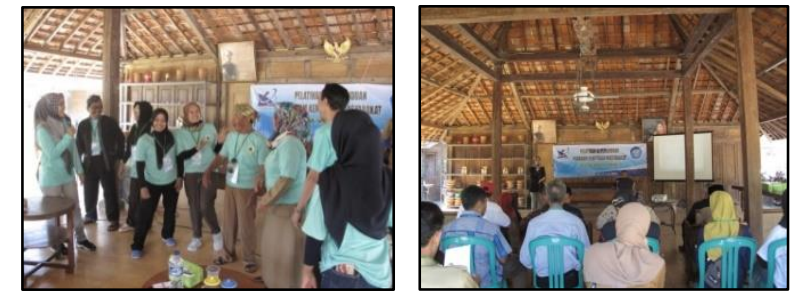
Tabel 4. Hasil Kegiatan Pelatihan

\begin{tabular}{|c|c|c|c|c|c|c|c|c|}
\hline NO. & NAMA KEGIATAN & \multicolumn{6}{|c|}{$\begin{array}{l}\text { TANGGAL DAN DURASI WAKTU } \\
\text { PELAKSANAAN }\end{array}$} & HASIL \\
\hline 1. & $\begin{array}{l}\text { Penguatan data melalui } \\
\text { diskusi dengan } \\
\text { Kompepar dan perangkat } \\
\text { desa serta survey }\end{array}$ & \multicolumn{6}{|c|}{$\begin{array}{l}28 \text { Juli } 2019 \text {, Jam } 13.30-22.00 \text {. oleh : Tim dan } \\
\text { para narasumber materi }\end{array}$} & $\begin{array}{l}\text { Data Jumlah anggota } \\
\text { kompepar dan tingkat } \\
\text { kompetensi dan wawasan } \\
\text { untuk kepemanduan. }\end{array}$ \\
\hline 2. & $\begin{array}{l}\text { Pembekalan Materi : } \\
\text { Wawasan Pariwisata }\end{array}$ & \multicolumn{6}{|c|}{$\begin{array}{l}29 \text { Juli 2019, Jam } 08.30 \text { - 09.30, oleh : Lia } \\
\text { Afriza, S.E.,M.M }\end{array}$} & $\begin{array}{l}\text { Peserta pelatihan mulai } \\
\text { meningkatkan wawasan } \\
\text { dalam hal arti dan manfaat } \\
\text { desa wisata serta } \\
\text { penambahan wawasan } \\
\text { tentang produk-produk yang } \\
\text { dihasilkan oleh masyarakat } \\
\text { desa cibuntu seperti gerabah, } \\
\text { suling, angklung, karinding } \\
\text { sehingga dapat memperkaya } \\
\text { materi dalam kegiatan } \\
\text { penjelasan saat memandu. }\end{array}$ \\
\hline 3. & $\begin{array}{l}\text { Pembekalan Materi : } \\
\text { Wawasan Pariwisata } \\
\text { (Sapta Pesona dan Sadar } \\
\text { Wisata) }\end{array}$ & \multicolumn{6}{|c|}{$\begin{array}{l}29 \text { Juli 2019, Jam } 09.30 \text { - 10.30, oleh : Titing } \\
\text { Kartika, S.Pd.,M.M, MBA Tourism }\end{array}$} & $\begin{array}{l}\text { Peserta pelatihan dikuatkan } \\
\text { kembali untuk hal } \\
\text { penggunaan sapta pesona dan } \\
\text { kegiatan darwis }\end{array}$ \\
\hline 4. & $\begin{array}{l}\text { Pembekalan Materi : Etika } \\
\text { Pelayanan } \\
\text { (Di Industri Pariwisata) }\end{array}$ & \multicolumn{6}{|c|}{$\begin{array}{l}29 \text { Juli } 2019 \text {, Jam } 10.30 \text { - 12.00, oleh : Khoirul } \\
\text { Fajri, S.E.,M.M }\end{array}$} & $\begin{array}{l}\text { Peserta pelatihan diberikan } \\
\text { wawasan perihal } \\
\text { aturan dan norma dalam } \\
\text { pelayanan kepemanduan }\end{array}$ \\
\hline 5. & $\begin{array}{l}\text { Pembekalan Materi : } \\
\text { Bahasa Inggris Dasar } \\
\text { Dalam kepemanduan } \\
\text { Wisata }\end{array}$ & \multicolumn{6}{|c|}{$\begin{array}{l}29 \text { Juli 2019, Jam } 13.00 \text { - 14.00, oleh : Septy } \\
\text { Indrianty, S.Pd.M.Pd }\end{array}$} & $\begin{array}{l}\text { Peserta pelatihan diberikan } \\
\text { wawasan dalam } \\
\text { penggunaan dasar bahasa } \\
\text { Inggris dasar sehingga } \\
\text { dapat mempraktikkannya } \\
\text { dalam kepemanduan }\end{array}$ \\
\hline \multirow[t]{3}{*}{6.} & $\begin{array}{l}\text { Pembekalan Materi : } \\
\text { Teknik Dasar Dalam } \\
\text { Kepemanduan Wisata }\end{array}$ & \multicolumn{6}{|c|}{$\begin{array}{l}29 \text { Juli 2019, Jam } 14.00-16.00 \text {, oleh : Hadi } \\
\text { Mulyan, M.M.Par }\end{array}$} & $\begin{array}{l}\text { Peserta pelatihan diberikan } \\
\text { pengetahuan teknik } \\
\text { dasar dalam kegiatan } \\
\text { kepemanduan wisata shg } \\
\text { dapat mempraktikkannya } \\
\text { dalam kepemanduan }\end{array}$ \\
\hline & INDIKATOR PENILAIAN & \multicolumn{5}{|c|}{$\begin{array}{c}\text { HASIL RERATA PENILAIAN } \\
\text { OLEH INSTRUKTUR }\end{array}$} & \multirow{2}{*}{\multicolumn{2}{|c|}{ KETERANGAN }} \\
\hline & $\begin{array}{l}\text { SETELAH KEGIATAN } \\
\text { PELATIHAN }\end{array}$ & 1 & 2 & 3 & 4 & 5 & & \\
\hline 1 & $\begin{array}{l}\text { Greeting and welcoming } \\
\text { tourist }\end{array}$ & & & $\sqrt{ }$ & & & \multirow{3}{*}{\multicolumn{2}{|c|}{$\begin{array}{l}\text { sebelum kegiatan pelatihan, diawal pembukaan } \\
\text { dilakukan uji coba terlebih dahulu untuk } \\
\text { praktik simulasi kepemanduan wisata, akan } \\
\text { tetapi dari hasil penilaian dan pengamatan tim } \\
\text { serta para narasumber dari } 34 \text { peserta } \\
\text { pelatihan hanya ada } 2 \text { orang yang sanggup } \\
\text { untuk melakukan } 4 \text { praktik simulasi } \\
\text { kepemanduan wisata meskipun dari indikator }\end{array}$}} \\
\hline 2 & $\begin{array}{l}\text { Asking and giving tourist } \\
\text { information }\end{array}$ & & & $\sqrt{ }$ & & & & \\
\hline 3 & Preparing tour itineraries & & & $\sqrt{ }$ & & & & \\
\hline 4 & $\begin{array}{l}\text { Orientation meeting and } \\
\text { briefing }\end{array}$ & & & $\sqrt{ }$ & & & \multicolumn{2}{|c|}{ penilaian belum tercukupi semua. } \\
\hline
\end{tabular}




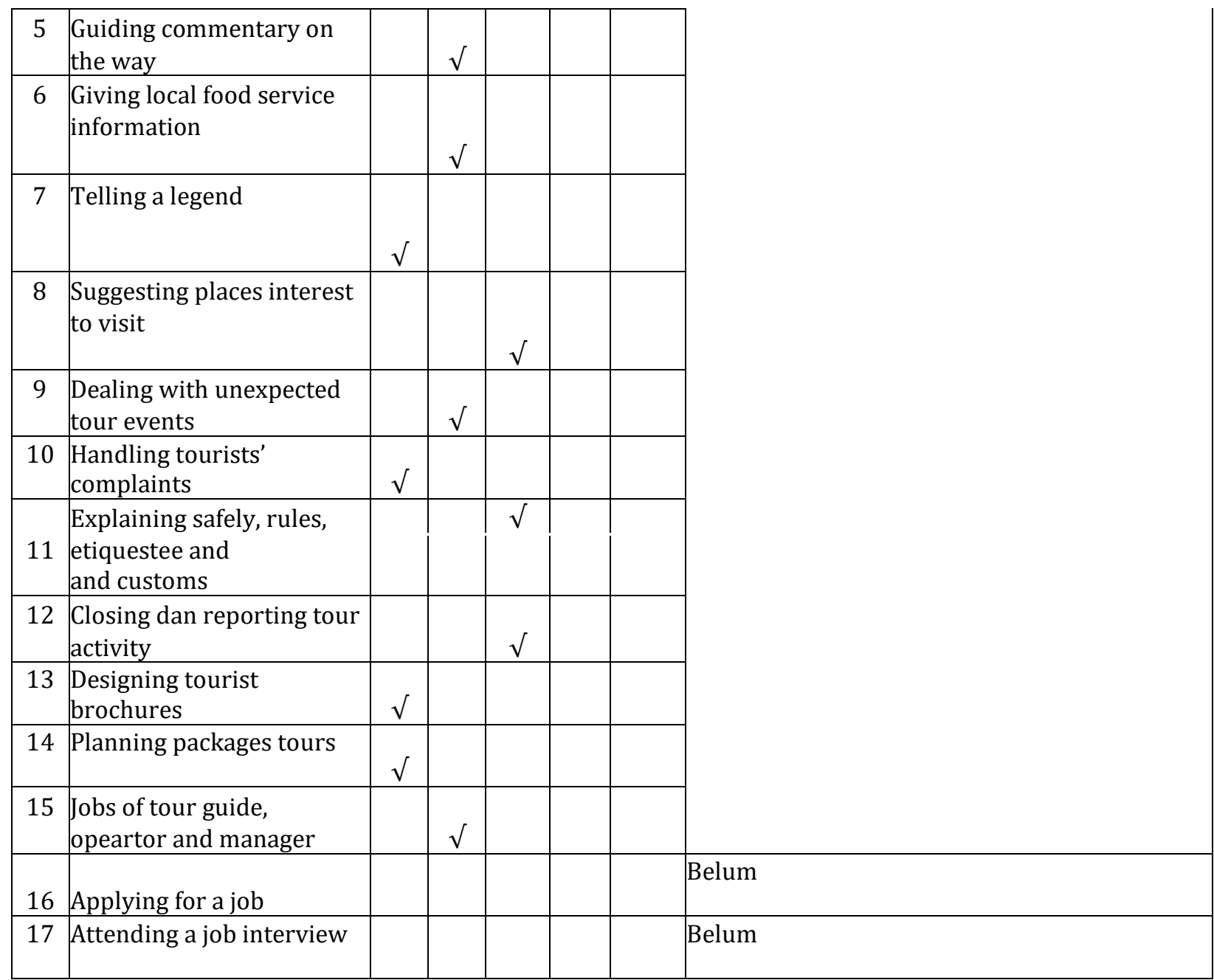

\section{KESIMPULAN}

\section{Kesimpulan}

Tiga komponen bidang kepemanduan yaitu skill (keterampilan teknik memandu), Knowledge (Pengetahuan bidang kepemanduan), Attutide (sikap dalam bidang kepemanduan). Begitu juga dengan aspek kemampuan berbahasa Inggris, pemandu wisata hendaknya merasa tidak takut berbahasa Inggris ketika memandu wisatawan mancanegara. Namun beberapa kosa kata.

Hal ini terjabarkan dalam 17 indikator teknik pelayanan kepemanduan wisata. Dari 17 indiktor tersebut belum diterapkan oleh sebagian besar masyarakat desa wisata Cibuntu saat melakukan kegiatan kepemanduan wisata di lingkungan bidang yang di kelolanya. Setelah dilakukan kegiatan pelatihan kepemanduan wisata dalam rangka program kemitraan masyarakat oleh STIEPAR YAPARI dengan anggaran dari dana hibah ristekdikti tersebut diharpakan akan mulai tumbuh nilai-nilai pelayanan kepemanduan yang saat pelaksanaannya mengaplikasikan indikator-indikator teknik kepemanduan wisata tersebut.

\section{Implikasi}

Dengan semakin meningkatnya prestasi desa wisata Cibuntu baik secara nasional maupun internasional, perlu adanya kegiatan pelatihan kepemanduan secara berkala yang dapat diadakan oleh pemerintah daerah setempat sehingga akan menjaga kelangsungan layanan kepemanduan wisata yang memenuhi kaidah-kaidah layanan dalam pemanduan wisata di desa Cibuntu tersebut. 


\section{UCAPAN TERIMAKASIH}

Terima kasih kepada Direktorat Riset dan Pengabdian Masyarakat Direktorat Jederal Penguatan Riset dan Pengembangan Kementrian Riset, Teknologi, dan Pendidikan Tinggi atas pendanaan kegiatan ini sesuai dengan Perjanjian Pendanaan Program Pengabdian Masyarakat Tahun 2018 Nomor: 13/SP2H/PPM/DRPM/2018. Terima kasih kepada Yayasan Terminal Hujan sebagai partner aktif kegiatan ini dan sebagai pengelola sumberdaya masyarakat mitra.

\section{DAFTAR PUSTAKA}

Adiyoso, W. 2009. Menggugat Perencanaan Partisipatif dalam Pemberdayaan Masyarakat.Jakarta: ITS Press

Darsono. 2005. Pengertian Desa. Diunduh tanggal 20 Mei 2016 dari: http://desasentonorejo.wordpress.co m/bab-ii/

Harum, A. 2012. Peranan Pramuwisata Dalam Memberikan Layanan Kedatangan Dan Keberangkatan. Di akses pada tanggal 19 Agustus 2018 di http://akademipariwisatakpg.blogspo t.co.id/2012/02/peranan- pramuwisata-dalam-

memberikan 16.html

Kesrul, M. 2004. Panduan Praktis Pramuwisata Profesional.

Yogyakarta:Graha Ilmu

Kementrian Pariwisata RI, 2014. Pesona Desa Wisata di Indonesia.Kemenpar

Leo, S. 2016. English for Professional Tour Guiding Services.Jakarta: PT.Gramedia Pustaka Utama

Sastrayuda ， G.S.,2010. Konsep Pengembangan Desa Wisata, Hand Out Mata Kuliah Concept

Resort and Leisure, Strategi Pengembangan dan Pengelolaan Resort and Leisure

Soemarno.2010. Desa Wisata. Piagam Pariwisata Berkelanjutan.

Surat Keputusan Kepala Dinas Pariwisata dan Kebudayaan Kabupaten Kuningan Nomor 55631/KPTS.178.A Disparbud/2012 tentang penetapan Desa Cibuntu sebagai Objek dan Daya Tarik Wisata (Desa Wisata)

Udoyono, B. 2008. Sukses menjadi Pramuwisata Profesional. Bekasi: Kesaint Blanc. 